\title{
12 Temmuz Beyannamesi’nin Demokrat Parti İçerisindeki Anlaşmazlığa Etkisi*
}

\section{The Effect of the July 12 Declaration on the Conflict within the Democratic Party}

\author{
İlhan Çeliker ${ }^{\mathrm{a}}$ \\ a Öğretim Görevlisi Dr, Bitlis Eren \\ Üniversitesi Tatvan MYO, Bitlis, \\ iceliker@beu.edu.tr, \\ Orcid No: 0000-0003-2662-3399.
}

\begin{abstract}
ÖZ
Türkiye'nin 1945 yılında çok partili sisteme geçmesiyle eski Başbakan Celal Bayar liderliğinde 7 Ocak 1946 tarihinde Demokrat Parti kurulmuştur. Kuruluşundan kısa bir süre sonra Demokrat Parti'nin halk tarafından ve değişik kesimlerden ciddi bir destek görmesi, bunu beklemeyen Cumhuriyet Halk Partisi'ni endişeye sevk etmiş ve ardından Demokrat Parti'ye karşı baskı politikasını beraberinde getirmiştir. 1947 yılının ortalarında iki parti arasında gerilen ilişkiler, çok partili sistemi tehdit edecek bir düzeye varmıştır. Bu aşamada Cumhurbaşkanı İsmet İnönü devreye girmiş ve tarihte '12 Temmuz Beyannamesi' olarak bilinen bildiriyi yayımlayarak iki parti arasındaki gerginliği azaltmaya çalışmıştır. $\mathrm{Bu}$ çalışmada 12 Temmuz Beyannamesi'nin ortaya çıkışı süreci ile Beyanname'nin Demokrat Parti'de önceden var olan parti içi anlaşmazlığa etkisi ve doğurduğu sonuçlar incelenmiştir.
\end{abstract}

Anahtar Kelimeler: 12 Temmuz Beyannamesi, Siyasi Partiler, Demokrat Parti, Çok Partili Sistem.

\begin{abstract}
Turkey's multiparty system in 1945 with the passing of the former Prime Minister Celal Bayar leadership on January 7, 1946, Democratic Party was established. The fact that Democratic Party received serious support from the public and different segments shortly after its establishment caused the Republican People's Party, who did not expect this, to worry, and then brought the policy of pressure against the Democratic Party. In the middle of 1947, when the tense relations between the two parties reached a level that threatened the multi-party system, President İsmet İnönü stepped in and tried to reduce the tension between the two parties by publishing the declaration known as the ' 12 July Declaration'in history. In this study, the process of the emergence of the 12 July Declaration and the effect of the Declaration on the pre-existing intra-party dispute in the Democratic Party and its consequences have been examined.
\end{abstract}

Keywords: July 12 Declaration, Political Parties, Democratic Party, Multi-Party System.

* Bu makalede bilimsel araştırma ve yayın etiği ilkelerine uyulmuştur. / In this article, the principles of scientific research and publication ethics were followed.

* Bu çalışma/makale, 27-28 Şubat 2021 tarihleri arasında çevrimiçi olarak düzenlenen "Munzur Zirvesi 3. Uluslararası Sosyal Bilimler Kongresi” başlıklı uluslararası sempozyumunda sunulan aynı başlıklı sözlü bildirinin genişletilmesiyle oluşturulmuştur. 


\section{GİRIŞ}

İkinci Dünya Savaşı sonunda kurulmaya çalışılan yeni dünya düzeni yanında, Türkiye'nin iç dinamikleri de siyasi rejimde değişiklik yapma ve böylece tek partili sistemden çok partili sisteme geçme zorunluluğunu ortaya çıkarmıştır (Karpat, 2013: 225; Demirel, 2016: 40-41; Akıncı \& Usta, 2015: 47). İkinci Dünya Savaşı'ndan galip çıkan Sovyet Rusya, 19 Mart 1945 'de, Türkiye ile 17 Aralık 1925 tarihinde imzalanan ve 7 Kasım 1945'de süresi dolacak olan Dostluk ve Saldırmazlık Antlaşması'nın İkinci Dünya Savaşı'yla ortaya çıkan yeni şartlardan dolayı yenilenmemesi konusundaki talebini Türkiye'nin Moskova Büyükelçisi Selim Sarper'e bildirmiştir. Antlaşmanın yenilenmesini isteyen Türkiye bu isteğini Rusya’ya iletmiştir. Sovyet Rusya ise yeni bir antlaşmanın imzalanması için şu sorunların çözülmesi gerektiğini belirtmiştir: "Türk-Sovyet doğu sınırında değişiklik yapılması, herhangi bir saldırı karşısında ortak savunma için Sovyetlere Boğazlarda üs verilmesi ve Montrö Sözleşmesi'nin yeniden gözden geçirilmesi." Sovyet Rusya'nın Türkiye ile ilgili emellerini açıça ortaya koyması, Türkiye’yi süratle Batı blokunun maddi ve manevi sahada bir mensubu olma mecburiyetinde bırakmıştır. Batı blokunda yer alabilmek için de mevcut sistemi değişstirmek ve daha demokratik bir sisteme geçmek gerekiyordu (Toker, 2020: 158; Erler Bayır, 2011: 47). Cumhurbaşkanı İsmet İnönü, değişiklikle ilgili ilk önemli işareti 19 Mayıs 1945 tarihli konuşmasında vermiştir. İnönü, savaşın bitmiş olmasından dolayı artık demokrasi yolunda yeni adımlar atılabileceğini belirtmiştir (Sadak, 1945: 1). Bu sürecin dönüm noktası ise, Cumhurbaşkanı İsmet İnönü’nün, 1 Kasım 1945 tarihli meclis açılış konuşmasında, ciddi bir muhalefet partisine ihtiyaç duyulduğunu açıkça bildirmesiydi (TBMM TD, Dönem VII, Toplantı 3, C. 20, 1 Kasım 1945: 7). Böylece, Türkiye'de çok partili sisteme geçmenin yolu bizzat Cumhurbaşkanı İnönü tarafından açılmış ve yeni bir dönem başlamıştır.

\section{2.İTIDDAR-MUHALEFET ÇATIŞMASI VE 12 TEMMUZ BEYANNAMESİ}

Çok partili sisteme geçme sürecinin Cumhurbaşkanı İnönü tarafından başlatılmasından sonra, Cumhuriyet Halk Partisi (CHP)'den ayrılan Celal Bayar ve arkadaşları parti kurma çalışmalarına başlamıştır. Bu arada İnönü, Bayar'1 Çankaya Köşkü’ne davet ederek kurulacak parti programı hakkında görüşmüştür. Görüşmede başta laiklik konusu olmak üzere bazı temel hususlarda görüş birliği sağlanmış ve İnönü ile Bayar'ın birlikte çalışması, daha sonra Demokrat Parti (DP) içindeki muhaliflerin de dillendireceği, Muvazaa Partisi iddialarını gündeme getirmiştir. Bayar ve arkadaşları tarafindan yürütülen çalışmaların tamamlanmasından sonra 7 Ocak 1946 tarihinde DP kurulmuştur (Eroğul, 2013b: 15-16; Afşar, 2019: 283). DP'nin kuruluş işlemleri çok kolay bir şekilde gerçekleştirilmiş ve kuruluşundan sonraki ilk dönemde, iktidar partisi CHP ile aralarındaki ilişki dostça olmuştur. CHP'nin beklentisi, kendi iktidarının devam etmesi ve bunun yanında bir muhalefet partisinin olması esası olmuştur. Buna göre, DP ülkenin tümünde teşkilatlanma yerine, sadece belli sayıdaki merkezlerde teşkilatlanmaya gidecektir. Dolayısıyla, DP'nin kısa vadede iktidara gelmek gibi bir hedefi olmayacak ve CHP iktidarı için bir tehdit oluşturmayacaktır (Bayar, 1986: 54; Karpat, 2013: 240).

Fakat ortaya çıkan yeni muhalefet modeli, CHP'nin hesaplarına tam olarak uygun bir gelişme göstermemiştir. DP, aşırı sol veya sağ bir parti olmamış, ancak beklenenden daha hızlı bir gelişme göstermesi CHP'yi hayal kırıklığına uğratmıştır. DP, kurulduktan kısa bir süre sonra, aydınların, basının, iş dünyasının ve geniş halk kitlelerinin desteğini hızla kazanarak tüm ülkede beklenenin ötesinde büyük bir heyecanla karşılanmıştır (Eroğul, 2013a: 179). Bu gelişmeler CHP ile DP arasındaki olumlu havayı bozmuş ve CHP'nin tavrı sertleşmeye başlamıştır. 31 Mart 1946 tarihinde DP kurucularından Adnan Menderes'in İzmir il merkezinde yaptığı basın toplantısı ve İçişleri Bakanının buna verdiği sert cevap, iki parti arasındaki gerginliğin başlangıcı olmuştur. Ciddi bir muhalefetin oluştuğunu gören CHP, bir yandan DP'ye karşı baskısını artırırken bir yandan da seçimleri öne almak suretiyle yeni bir iktidar dönemini başlatmak istemiştir. Bu amaçla Mayıs ayında yapılan belediye seçimlerine DP katılmamış ve genel seçimlerin de öne alınması durumunda bu seçime de katılmayacaklarını açıklamıştır (Bayar, 1986: 51-54). DP'nin izlediği bu siyasi tavır sonuçlar vermeye başlamış, CHP iktidarı genel seçimlerden önce bazı liberal düzenlemeler yapma yoluna gitmiştir. Bu doğrultuda, tek dereceli seçime imkân sağlayan bir yasa kabul edilmiş, Basın Kanunu liberalleştirilmiştir ve üniversitelere idari özerklik verilmiştir (Ahmad, 2010: 34-36).

DP’nin hızlı gelişmesi ve teşkilatlanması karşısında CHP iktidarı, bir yandan sözü geçen bazı liberal kararlar alarak halkın desteğini kazanmaya çalışmış, diğer yandan da muhalefete fazla imkân tanımamak gayesiyle, genel seçimleri bir yıl erkene alarak 21 Temmuz 1946'da yapılmasını kararlaştırmıştır (Cumhuriyet, 10 Haziran 1946). Daha yurt genelinde teşkilatlanmasını tamamlayamamış olan DP'nin tüm itirazlarına rağmen genel seçimlerin bir yıl erkene alınması DP yöneticilerini seçime katılma konusunda kararsızlığa sevk etmiştir (Eroğul, 2013b: 22). Nihayet örgütün de görüşünü almak amaciyla 15 Haziran'da Ankara'da geniş katılımlı bir toplantı yapılmış ve toplantı sonunda DP seçime katılma kararı almıştır (Cumhuriyet, 17 Haziran 1946).

21 Temmuz 1946 seçimleri iktidar partisi ile muhalefet arasındaki gerginliği artırmış ve tartışmanın seçimlerden sonra daha da şiddetlenerek devam etmesine sebep olmuştur. Çünkü seçim sürecinde iktidarın muhalefete karşı göstermiş olduğu tavır, muhalefette büyük bir kızgınlık ve öfke yaratmıştır. DP’ye göre, kendi parti teşkilatının sandık müşahitleri eliyle topladığı rakamlar dikkate alındığında çok daha fazla milletvekilliği kazanması gerekirken, DP 21 Temmuz seçimlerinde sadece 66 milletvekilliği kazanabilmiştir (Bayar, 1986: 62). Oysa DP'liler, bundan çok daha büyük bir desteğe sahip olduklarını gördükleri için seçimlerin hemen sonrasında, yapılan baskılar ve usulsüzlüklerle ilgili raporlar yağmaya başlamıştır. DP, daha resmi sonuçlar belli olmadan İnönü’ye bir telgraf göndererek haksızlığın düzeltilmesi için müdahalede bulunmasını istemiştir (Eroğul, 2013b: 23). Bu itirazların bir sonuç vermemesi üzerine Demokratlar, seçimi protesto amacıyla bir dizi miting tertiplemişlerdir (Cumhuriyet, 25-26 Temmuz 1946).

DP'ye göre, 21 Temmuz seçimlerinde iktidar tarafından kanun dışı işler yapılmış, bunun neticesinde adil olmayan bir seçim yapılmış ve bu kanunsuzluklara yapılan itirazlar da neticesiz kalmıştır. Bütün olanlara rağmen DP, partiyi ve memleketi sonu 
gelmez maceralara sürüklememek adına halkta oluşan öfkeyi yatıştırmak ve kanun içinde başlayan mücadeleyi kanun içinde kalarak devam ettirme kararı almıştır (Bayar, 1986: 59). DP'nin bu tavrı, cesur bir muhalefet hareketi olarak Türk siyasal hayatında, ilk defa geniş halk kitlelerinin taleplerini yöneticilere haykırmak olarak yorumlanmıştır (Eroğul, 2013a: 179-180).

21 Temmuz seçimlerden sonra İnönü yeniden Cumhurbaşkanı seçilmiş ve hükümeti kurma görevini Recep Peker'e vermiştir (Cumhuriyet, 6 Ağustos 1946). Hem tek partili sistem hem de kuvvetli bir şef yönetimi taraftarı olan Recep Peker, aynı zamanda muhalefetle uzlaşmadan yana olmayan bir kişilik ortaya koymuştur. Peker'in izlediği siyaset, CHP'nin yanı sıra DP içinde de gittikçe artan bir ayrışmayı beraberinde getirmiştir. Recep Peker Hükümeti döneminde muhalefet üzerinde uygulanan baskı politikası, iktidar-muhalefet ilişkilerini daha da germiştir (Çaylak \& Nişanc1, 2012: 312). Recep Peker'in 18 Aralık 1946 tarihinde Menderes'in bütçe eleştirilerine verdiği cevapta kullandığı sözler iki parti arasındaki ilişkileri oldukça germiştir. Peker'in;

\section{Adnan Menderes'in sesinde kötümser ve psikopat bir ruhun mariz karanlıklar içinde, şanlı bir milletin ve arkada bıraktı̆̆ karanlıklardan azametli, şan ve şerefli bir istikbale gitmek azminde bulunan kudretli bir devletin hayatını bir boşluk halinde ifade eden ruh haletinin akislerini dinledik}

biçiminde bir cümleyi kullanması üzerine DP Meclis’i terk etmiştir (TBMM TD, Dönem VIII, Toplantı 1, C. 3, 18 Aralık 1946: 23-24). Daha sonra, Cumhurbaşkanı İnönü, Celal Bayar ile Fuat Köprülü’yü Çankaya Köşkü’ne çağırarak hadiseden duyduğu teessürü bildirmiş ve kendilerini tekrar meclis müzakerelerine katılmaya ikna etmiştir. Fakat bu olumlu gelişmeye rağmen iktidar-muhalefet gerilimi bitmemiştir (Uran, 2017: 377).

İki parti arasındaki gerginlik, DP Milletvekili Sadık Aldoğan’ın, meclisteki bir konuşmasında, yürürlükteki sıkıyönetim idaresini kasten söylediği; "mutlakıyet idaresine rahmet okutacak zalimane bir idare tarzı" sözlerini geri almaması üzerine 15 gün süreyle meclisten çıkarma cezası almasıyla zirveye ulaşmıştır (Akın, 2005: 93). 1947'nin ortalarına gelindiğinde iktidar ve muhalefet arasındaki gerginliğin vardığı boyut, artık çok partili sisteme devam edilemeyeceği korkusunu oluşturmuştur. Bunun üzerine, Cumhurbaşkanı İsmet İnönü devreye girmiş ve hem Hükümet hem de muhalefet partisi temsilcileri ile görüşmeler yapmıştır (Eraslan, 1998: 144). Önce 6 Haziran'da Fuat Köprülü’yü davet ederek konu hakkında görüşmüştür. Köprülü, ortamın gergin olduğunu ve ilerisi için iyi olmayacağını belirtmiş, İnönü de iki taraf arasında bir güven sorunu olduğunu, DP'lilerin halkı ayaklandırmak, insanları öldürmek gibi telkinler yaptıklarını ve bunun doğal olarak endişe uyandırdığını ifade etmiştir. Köprülü, kendisinin ve arkadaşlarının şiddetle bu söylemlerin karşısında olduklarını İnönü’ye aktarmıştır (İnönü, 2017: 333-334). Metin Toker, DP yöneticilerinin, iktidarı alsalar bile İnönü’yü iki partinin ortak adayı olarak Cumhurbaşkanı yapacaklarına dair bir senaryo geliştirdiklerini ve buna İnönü'nün de inandığını aktarmaktadır. DP'lilerin 1947-1949 arasında bu oyalamayı mükemmel bir şekilde yaptıklarını, halkın önünde farklı konuştuklarını, fakat İnönü’ye farklı bir söylemle gittiklerini bildirmektedir. Bu süreçte Köprülü önemli bir işlevi yerine getirmektedir. Fuat Köprülü, Nihat Erim ile gerçekleştirdiği görüşmeler üzerinden Cumhurbaşkanı İnönü’ye DP’nin bu yöndeki görüşlerini ileten kişidir (Toker, 2020: 155).

İnönü, daha sonra konuyu 7 Haziran’da DP Genel Başkanı Celal Bayar'la görüşmüştür. Bayar, idari amirler tarafından şiddetli bir baskıya maruz kaldıklarını, bazı yerlerde teşkilatlarının tehditle kapatıldığını, partisine mensup olanların dövüldüğünü ve işten çıkarıldığını belirtmiştir. İnönü de Köprülü’ye söylediklerini tekrar etmiş ve Bayar'ın anlattıklarını Hükümet tarafına aktaracağını ve bir çıkar yol bulmaya çalışacağını söylemiştir. İnönü aynı akşam Başbakan Peker'le de konuyu görüşmüş ve olumlu bir cevap alamamıştır (İnönü, 2017: 334-335).

İnönü, konuyu CHP Genel Sekreteri Hilmi Uran ve diğer CHP yetkilileriyle konuştuktan sonra, tekrar 11 Haziran'da Bayar'la bir araya gelmiştir. İnönü, DP'nin şikâyetlerini elinden geldiğince karşı tarafa aktardığını ve onların da şikâyetlerinin olduğunu belirttikten sonra, iki tarafı bir araya getirerek karşılıklı konuşmalarını istediğini ve taraflar arasında güveni artıracak bir çözümü bulmaya çalışacağını, bu konuda kendisine yardımcı olmalarını istemiştir. Bayar da kanuni yollarda çalışmaktan başka amaçlarının olmadığını ve bir neticeye varmaktan memnun olacaklarını belirtmiştir. Bunun üzerine, 14 Haziran'da İnönü, iktidar partisinden Başbakan Peker, yardımcısı Mümtaz Ökmen ve DP Genel Başkanı Bayar ile iki taraf arasındaki münasebetleri görüşmek amacıyla bir araya gelmiştir. Her iki taraf daha önce dile getirdikleri şikâyetlerini ve beklentilerini uzun uzun anlatmışlardır. Görüşmenin sonlarında oluşan olumlu hava, İnönü’nün temaslarını sürdürmesine vesile olmuştur. İnönü, sonraki süreçte taraflarla gerçekleştirdiği bir dizi görüşmeden sonra, nihayet 10 Temmuz'da Bayar'la yaptığ 1 görüşmede yayımlamayı düşündüğü beyanname üzerinde mutabakata varmıştır (İnönü, 2017: 337-344).

İnönü, iktidar ve muhalefet temsilcileriyle gerçekleştirdiği görüşmeler sonunda '12 Temmuz Beyannamesi’ olarak bilinen bir Cumhurbaşkanlığı bildirisi yayımlamıştır. İnönü, 11 Temmuz günü akşam saatlerinde radyoda yayımlanan beyannamesinde, iktidar partisi CHP ile muhalefet partisi DP arasındaki gerginliği gidermek için taraflarla yaptığı görüşmeleri ve genel anlamda iddialarını aktardıktan sonra, kendi tespitlerini ve geleceğe yönelik beklentilerini açıklamıştır. İnönü, gerçekleştirdiği görüşmelerde muhalefet partisi DP Başkanı Bayar'ın partisinin baskı altında olduğunda 1srar ettiğini, partisinin kanun dişı maksatlar ve ihtilal usulleri takip etmediğini söylediğini, Başbakan Peker'in ise baskı iddialarını ret ettiğini, şikâyet belgelerini tetkik ve takibe hazır olduklarını, ayrıca muhalefet partisinin çalışma yöntemlerini düzeltmesi gerektiği yönündeki söylemini aktarmıştır. İnönü, görüşmelerin sonunda; “idare mekanizmasının baskı yaptığını hükümet reisinin kabul etmemesini” iktidar tarafının, "muhalefet liderinin kanun dışı maksatlar ve metotlar isnadını reddetmesini, muhalif parti çalışması için şart olan kanun içinde kalmak esasının göz önünde tutulduğuna ve tutulacă̆ına dair tatmin edici” beyanını da muhalefet tarafının teminatı olarak kabul ettiğini ve bunları karşı tarafa aktardığını bildirmiştir. Bir buçuk seneden beri yaşananların ağır ve bazen ümit kırıcı olduğunu, ama gelecek için her türlü ümitleri haklı çıkaracak bir başarının da temin edildiğini, bu durumu muhafaza etmek ve onun gelişmesini sağlamanın, iktidar ve muhalefet partilerinin görevi olduğunu hatırlatmıştır. İnönü, dinlediği karşılıklı 
şikâyetler içerisinde gerçeklik payı bulunduğunu, muhalefetin isyancı bir örgüt değil meşru bir siyasal parti olduğunu ve Cumhurbaşkanı olarak, hem iktidara hem de muhalefete karşı eşit davranmakla vazifeli olduğunu ilan etmiştir (Cumhuriyet, 12 Temmuz 1947).

\section{DP'DE BÖLÜNME}

Cumhurbaşkanı İnönü’nün ortaya koyduğu tavır ve yayımlanan beyanname hem iktidar hem de muhalefetin çoğunluğu tarafından olumlu bir gelişme olarak karş1lanmıştır. Ulus gazetesinin, “İönü'den yalnız şu parti veya bu grup değil, bütün rejim faydalanmalı, partiler liderleri başları dara geldiği anda onun masası başında toplanmalıdırlar." şeklindeki beyanı hem yürütülen sürece hem de İnönü'nün yeni geliştirdiği partiler üstü rolüne verilen desteği göstermektedir. Diğer taraftan DP Genel Başkanı Celal Bayar, Beyanname ile ilgili görüşünü şöyle dile getirmiştir: "12 Temmuz Beyannamesi bizi dağltma ve yok etme teşebbüslerine karşı bütün Demokratların, hatta Türk milletinin gösterdiği celadetin ve sarsılmaz iradenin mahsulü olarak ortaya çıktı ...” DP'nin önemli isimlerinden Fuat Köprülü de, Cumhurbaşkanı İsmet İnönü ve 12 Temmuz Beyannamesi için şunları söylemiştir: “Inönü’nün beyannamesi memlekette yeni bir hayat neşesi yaratacaktır. Devlet reisinin Türk milletine neşrettiği bu tebliğ, dünya ve memleket şartlarını samimiyetle ve cesaretle kavrayan tarafsı bir devlet reisinin en buhranlı dakikada en isabetli bir kararının parlak bir ifadesidir" (Toker, 2020: 154, 183).

Gazeteci Nadir Nadi de Beyannamenin taşıdığı önemi şu şekilde ifade etmiştir:

Cumhurbaşkanı'nın günlerden beri sabırsızlıkla beklenen demeci bütün yüreklerde derin bir memnunluk uyandırdı. Zaman zaman bir çıkmaza girmek istidadı gösteren iki parti arasındaki münasebetlerin bundan böyle normale doğru hızlı adımlarla gelişeceğini kuvvetle ümid edebiliriz. Bir yıllık çetin tecrübelerden sonra Sayın İönü bize doğru yolu işaret etmek imkânını bulmuştur. Siyasi hayatımızın aydın ufuklara kavuşabilmesi için bu yolu bulmak ve onun üzerinde ısrarla yürümek şarttı. Devlet Reisi tarafindan yayınlanan demeç bu itibarla rejimimizin tarihinde bir ileri merhale değerindedir (Nadi, 1947: 1).

12 Temmuz Beyannamesi, çok partili düzene geçiş sürecine sağladığı katkı yanında, aynı zamanda hem iktidar partisi CHP'nin hem de bu süreçte tek partili rejime karşı muhalefetin merkezi durumunda bulunan ve farklı görüşteki kişilerin toplandığı DP'nin içyapısını oldukça etkilemiştir. Ancak DP içindeki anlaşmazlık ve mücadele, CHP içerisindeki anlaşmazlık ve sonuçlardan çok daha öteye giderek, parti içerisinde bölünmeye yol açmış ve yeni bir parti ortaya çıkarmıştır (Haytoğlu, 1994: 41; Demirel, 2016: 63; Toker, 2020: 172). Beyannameyle beraber DP ile iktidar partisi CHP arasındaki gerginliğin azalmasıyla DP içinde var olan kişisel farklılıklar ve çekişmeler iyice açığa çıkmaya başlamıştır (Eroğul, 2013b: 50). Ayrıca, sürecin devamında 17 Kasım 1947'de toplanan CHP 7. Kurultayında yapılan değişiklikler ve muhalefete karşı sertlik yanlısı olan Başbakan Recep Peker'in istifasıyla muhalefet üzerindeki hükümet baskısının kalkması da DP'deki kişisel çatışmaların ortaya çıkmasına katkı sağlamıştır (Kabasakal, 1991: 176; Uran, 2017: 385).

Aslında DP'nin dört kurucusuna karşı 1947 yılının başlarından itibaren DP içerisinde bir muhalefet oluşmaya başlamıştır. Muhalif grup, 7-11 Ocak 1947 tarihlerinde yapılan Birinci Büyük Kongre'den itibaren harekete geçmiştir. Kendi aralarında da fikir ve ideal beraberliği olmamasına rağmen Yusuf Kemal Tengirşenk, Osman Bölükbaşı, Ahmet Tahtakılıç, Kenan Öner gibi kişiler DP kurucularına karşı muhalif grupta yer almıştır (Ağaoğlu, 2013: 78). Muhaliflerden bazıları kongre esnasında CHP yönetimine karşı DP'yi zor durumda bırakan çok sert konuşmalar yapmıştır. Ayrıca Kongre başkanının kim olacağı, Genel İdare Kurulunun kaç kişiden oluşacağı ve kimlerin yer alacağı konularında da DP kurucuları ile muhalifler arasında sert tartışmalar yaşanmıştır (Çaylak, 2007: 24-25).

DP içinde 1947 yılının başlarından itibaren oluşan muhalif grup, 12 Temmuz Beyannamesi görüşmelerinden itibaren daha açık bir şekilde muhalefete geçmişlerdir. Bayar, İnönü ile 6 Haziran'daki ilk görüşmeden hemen sonra Genel İdare Kurulunu toplayarak konu hakkında bilgi vermiştir. Muhalifler hem görüşmelerin sürdürülmesine karşı çıkmışlardır hem de süreç sonunda ortaya çıkan Beyannameyi onaylamak istememişlerdir. Beyanname yayımlanmadan önce bir nüshası İnönü tarafından Bayar'a verilmiştir. Bayar, 10 Temmuz 1947 tarihinde DP Genel İdare Kurulunu toplayarak, İnönü ile yaptıkları görüşmeler hakkında bilgi vermiş ve beyanname metnini açıklamıştır. Kurul üyeleri arasında Beyanname hakkında görüş farklılıkları ortaya çıkmıştır. Celal Bayar, Adnan Menderes ve Fuat Köprülü, Beyannamenin faydalı olacağını, teşkilatın iyice güçsüz kaldığını, mevcut durumu sürdürmenin teşkilattaki arkadaşları tehlike içinde bırakmak anlamına geleceğini ve buna razı olmadıklarını, ayrıca Beyannamenin DP'ye karşı vatandaşların var olan endişelerini gidereceğini ve Cumhurbaşkanı ile Başbakanı bağlayan bir belge olacağını ileri sürmüşlerdir. Diğer taraftan Ahmet Oğuz, Yusuf Kemal Tengirşenk ve Ahmet Tahtakılıç ise Beyanname’ye karşı çıkmışlardır. Bunlara göre, Cumhurbaşkanı İnönü yetkisi ve hakkı olmayan bir işe kalkışmaktadır, Beyannamenin kabul edilmesi halinde İnönü'nün bu davranışı meşrulaştırılmış olacaktır ve parti O’nun nüfuzu altına girmiş olacaktır. Yapılması gereken, Beyannameyi reddederek dişe diş, tırnağa tırnak mücadele etmektir. Uzun görüşmelerden sonra Beyanname, Tengirşenk'in ret oyuna karşı oy çokluğuyla kabul edilmiştir (Bayar, 1986: 85-86; Goloğlu, 1982: 169-170).

DP kurucuları ve üst yönetimine göre, 12 Temmuz Beyannamesi DP üzerindeki baskıyı hafifletecek ve partinin rahat bir nefes almasına firsat verecektir. Bu rahatlama da partiyi daha da güçlendirecektir. Muhalif grup ise; CHP'nin çeşitli baskı ve yıldırma metotlarıyla yapamadığını, başka bir yöntem kullanarak, güler yüzle DP'yi nüfuzu altına almaya çalıştığını ve DP'nin mücadele ruhunu öldürmek istediğini ileri sürmüşlerdir (Bayar, 1986: 85-86; Karpat, 2013: 294-298). Ayrıca, bildiriyle beraber iktidar ve muhalefet arasında oluşan bahar havası, muhaliflerden Kenan Öner ve onu destekleyen Osman Nuri Köni, Mithat Sakaroğlu, Necati Erdem, Kemal Silivrili ve Hazım Bozca tarafından CHP ile muvazaa olarak değerlendirilmiştir (Güzelipek, 2017: 80). 
Cumhurbaşkanı İnönü’nün 12 Temmuz Beyannamesi iktidar partisi CHP'yi etkilemişse de asıl etkisini, DP'de göstermiştir. Bu etki DP'nin İkinci Büyük Kongre'sine kadar sürmüş ve nihayetinde milletvekillerinin yarısına yakınının partiden ayrılarak yeni bir parti kurmalarına yol açacak kadar vahim olmuştur (Şeyhanlığlu, 2012: 90). İnönü’nün Beyannamede;

Sorumlu hükümetin huzur ve asayiş vazifesi münakaşa götürmez. Fakat, meşru ve kanuni siyasi partilere karşı tarafsız, eşit muamele mecburiyeti, siyasi hayat emniyetinin temel şartıdır. Bu arada, siyasi partilere mensup olan veya görünen hususi maksat sahiplerinin şirretliklerini pervasız olarak tesirsiz bırakmak hususunda partilerin dikkat göstermeleri icap eder.

şeklindeki söylemi, hem CHP'ye hem de DP'ye mesaj olarak algılanmıştır. Her iki parti içerisindeki radikal eğilimlilerin hedef alındığı ve özellikle "siyasi partilere mensup veya görünen" söylemiyle DP içerisindeki muhalif ve sertlik yanlısı olan kesime yönelik göndermeler olarak değerlendirilmiştir. Bu açıdan değerlendirildiğinde, daha sonra DP içinde meydana gelen ayrışmalara bakılarak, yapılan göndermelerin süreç içerisinde sonuçlar verdiği de söylenebilir (Çiçek, 2018: 90-91).

12 Temmuz Beyannamesi'nin CHP ve DP üzerindeki etkileri devam ederken Cumhurbaşkanı İnönü, Eylül 1947’de Doğu Anadolu ile Orta/Doğu Karadeniz illerini kapsayacak olan bir yurt gezisine çıkmıştır. Kendisini iki partiye karşı eşit derecede görevli gördüğünü göstermek için yurt gezisine çıkmadan önce Bayar'la görüşerek, kendisinin yurt gezisine eşlik etmesi için DP'den de bir milletvekili istemiştir. DP yönetimi bu gezi için Muğla Milletvekili Nuri Özsan’1 görevlendirmiştir. İnönü, bu 14 günlük gezi esnasında Özsan’ı devamlı yanında bulundurmuş ve yakından ilgilenmiştir. Bu gezi ile ilgili dikkat çekici diğer bir nokta da İnönü’yü Ankara garında yolculayanlar ve dönüşünde karşılayanlar arasında DP kurucularından Fuat Köprülü’nün bulunmasıdır (Ateş \& Gökçeler, 2019: 485). Ayrıca İnönü, gezi esnasında gittiği yerlerde DP’liler tarafından da karşılanmış ve DP parti teşkilatlarını ziyaret etmiştir. Tarafsızlığını göstermek için Erzurum ziyareti sırasında valiye ve umumi müfettişe her iki partiye de eşit dikkatle yardımcı olmalarını istemiştir. (Cumhuriyet, 17 Eylül 1947).

İnönü’nün bu gezisi DP içindeki fikir ayrılıkları ve mücadeleyi iyice hızlandırmıştır. DP içindeki muhaliflerin iddiasına göre, gezi esnasında İnönü, iki parti arasındaki ilişkilerin daha da ilerlemesi için DP içindeki bazı kişilerin tasfiye edilmesi gerektiğini Nuri Özsan'a hissettirmiştir. İşaret edilen kişiler Sadık Aldoğan, Kenan Öner, Ahmet Tahtakılıç, Yusuf Kemal Tengirşenk’tir (Eroğul, 2013b: 50).

12 Temmuz Beyannamesi’yle artık açık bir şekilde tavır alan DP içindeki muhaliflerin DP'den tasfiye-istifa sürecini başlatacak olan milletvekillerinin ödenekleri konusu da İnönü’nün bu gezisi esnasında gündeme gelmiştir. İnönü, milletvekillerinin maddi sıkıntı yaşadıklarını öğrendiğini ve bu konuda Nuri Özsan'ın da fikrini aldıktan sonra, Özsan'a yeni bir düzenleme ile konunun düzeltilebileceğini söylemiştir (Haytoğlu, 1994: 42). Bunun üzerine milletvekilleri maaşlarına zam yapılması teklifi 1947 Aralık ayında Meclise getirilmiştir. DP Genel İdare Kurulu zam teklifi konusunda parti içerisinde dillendirilen farklı görüşler karşısında son kararını vermiştir. Buna göre, Mecliste teklifin aleyhinde oy verilecek, ancak zam teklifi çoğunluğun oylarıyla geçtiği takdirde farklar partiye bağışlanacaktır (Eroğul, 2013b: 51).

Bazı milletvekillerinin şiddetle karşı çıkmalarına rağmen zam teklifi 22 Aralık 1947 tarihinde 66 muhalif oya karşı 231 oyla kabul edilmiştir (Cumhuriyet, 23 Aralık 1947). Zam teklifine olumlu oy verenler arasında DP Milletvekili Ahmet Kemal Silivrili de vardır ve Silivrili bu davranışından dolayı Haysiyet Divanı'na verilmiştir (Ağaoğlu, 2013: 103).

DP içindeki gerginlik ve çatışma, 1948 yılının ilk günlerinde muhaliflerin önde gelen isimlerinden İstanbul İl Başkanı Kenan Öner ile parti kurucularından Köprülü arasında şiddetlenerek devam etmiştir. Öner, Köprülü ve diğer DP kurucularına tepki olarak önce il başkanlığından, 16 Ocak'ta da DP'den istifa etmiştir (Cumhuriyet, 17 Ocak 1948). Kenan Öner'in istifasından sonra Öner-Köprülü çekişmesi, Öner'i destekleyenlerin çoğunlukta olduğu Meclis Grup Yönetim Kurulu ile Köprülü’yü destekleyenlerin çoğunlukta olduğu partinin karar organı Genel İdare Kurulu anlaşmazlığına dönüşmüştür (Ağaoğlu, 2013: 122-123).

Parti kurucuları ile muhalifler arasında devam eden mücadele Şubat ayında farklı bir boyuta ulaşmıştır. Genel Başkan Bayar, Genel İdare Kurulu kararına rağmen maaş farklarını Parti’ye vermeyen 19 muhalif milletvekilinin ismini, onları zor durumda bırakmak amacıyla 14 Şubat'ta basın ile paylaşmıştır (Cumhuriyet, 15 Şubat 1948).

DP içinde 1947'nin başlarından beri var olan, 12 Temmuz Beyannamesi’yle açık bir duruma dönüşen parti içi çekişme ve mücadele 1948 yılı Mart ayında bölünme ile sonuçlanmıştır. Muhaliflerin çoğunlukta olduğu Meclis Grubu, Bayar’ın yerine Grup Başkanlığına muhalif Fuat Hulusi Demirelli’yi, başkanvekilliğine ise Ahmet Tahtakılıç'1 seçmiştir. Bunun üzerine harekete geçen Genel İdare Kurulu, parti disiplinine aykırı davrandıkları gerekçesiyle beş milletvekilini ihraç istemiyle Yüksek Haysiyet Divanı'na vermiştir. Yüksek Haysiyet Divanı 10 Mart'ta toplanarak beş milletvekilinin partiden çıkarılmasına karar vermiştir (Eroğul, 2013b: 52-53; Goloğlu, 1982: 233). Bunun üzerine Ahmet Oğuz, Ahmet Tahtakılıç, Emin Sazak, Enis Akaygen, Hasan Dinçer, Yusuf Kemal Tengirşenk’ten oluşan altı kişi tepki olarak Genel İdare Kurulu üyeliğinden istifa etmişlerdir. Daha sonra bu altı kişi partiden çıkarılmıştır. Altı kişinin partiden çıkarılmasına tepki gösteren on milletvekili ise, bir bildiri yayımlayarak arkadaşlarının tekrar Parti’ye alınmasını istemişler ve artık grup toplantılarına katılmayacaklarını bildirmişlerdir. Genel İdare Kurulu da 7 Mayıs 1948 tarihinde bu on milletvekilinin partiye zarar verdiklerini karara bağlayarak bunları Parti'den attırmıştır. Bunların yanında iki milletvekili daha istifa etmişstir ve böylece DP'nin Meclis'teki sayısı 61'den 31'e inmiştir (Karpat, 2013: 304; Goloğlu, 1982: 233).

1948 yılının ortalarına gelindiğinde, muhaliflerin bir kısmı DP'den istifa etmiş, bir kısmı partiden atılmışlardır. DP'yle yolları bir şekilde ayrılanların bazıları 1948 yılında yeni bir siyasi parti (Millet Partisi) kurarak yollarına devam etmiş, bazıları 
da Müstakil Demokratlar Grubu adı altında DP’nin 1949 yılındaki İkinci Büyük Kongresi’ni bekledikten sonra, istedikleri neticeyi alamamaları üzerine önemli bir kısmı Millet Partisi’ne katılmıştır. Böylece DP büyük bir fırtına atlatmış ve bu kargaşadan hem kurucular daha güçlenerek çıkmışlardır hem de DP daha homojen bir yapıya dönüşmüştür (Yaşar Teksoy, 2010: 140-144). Diğer taraftan başta Mareşal Fevzi Çakmak olmak üzere Millet Partisi'ni kurunlar tarafından, DP'nin CHP'ye karşı gerçek bir alternatif olmadığı ve de DP’nin bir muvazaa partisi olduğu iddiası ileri sürülmüştür (Limoncuoğlu, 2018: 147-148).

Bütün bu gelişmelerin merkezinde yer alan DP Genel Başkanı Bayar, DP içindeki muhaliflerin 12 Temmuz Beyannamesi sürecini gerekçe göstererek yollarını ayırdıklarını, fakat bu bildiri olmasa bile muhaliflerin başka bir konu bulup ayrılıklarını sürdüreceklerini iddia etmiştir. Bayar'a göre, muhaliflerin hiç birinin gayede kendilerinden farklı düşünmediğini, fakat bu gayeye varabilmek için farklı farklı yollar teklif ettiklerini belirtmiştir (Bayar, 1986: 90-91).

Samet Ağaoğlu ise, DP'deki ayrışma ve çatışmayı Fuat Köprülü-Kenan Öner çekişmesi üzerinden açıklamıştır. Ağaoğlu'na göre, DP'nin daha ilk yılında bu iki aktör sahneye sürülmüş, fakat asıl çatışma bunların arkasına gizlenen eski kurt bir politikacı olan Yusuf Kemal Tengirşenk ile Adnan Menderes arasında olmuştur. Bu kavganın galibi olan Menderes, ileriki iktidarın da başı olmuştur (Ăgaoğlu, 2013: 123-124).

Kemal H. Karpat'a göre, DP'deki ayrışmanın esas sebebi parti içerisinde farklı kişilerin toplanmış olmasıdır. Milletvekilleri maaşlarının artırılması konusunda DP liderlerinin çok çelişik bir tutum takındıklarını, daha sonra kamuoyu baskısıyla tavırlarını netleştirdiklerini belirtmektedir. Disiplini sağlamak adına muhaliflerin partiden tasfiye edilmesinin de üst yönetimin tahakküm eğilimine bağlayan Karpat, istibdadın bir çeşidine son verilmeye çalışılırken başka bir istibdat çeşidine başvurulduğuna işaret etmektedir. Karpat'a göre DP içindeki ayrışmanın başka önemli bir nedeni de, İnönü'nün açılımlarına paralel olarak DP yöneticilerinin de İnönü'ye karşı söylemlerini yumuşatmalarına karşın, muhaliflerin buna yanaşmamaları olmuştur (Karpat, 2013: 304-305).

\section{DP içindeki ayrışmayı Metin Toker de şu şekilde izah etmiştir:}

DP'de 'müfrit-ılımlı' ayrılı̆̆ olaylarla başlamadı, şahısların tabiatları, karakterleriyle başladı. Bayar ne kadar sabırlı, hesapl, mütehammil ise Kenan Öner o derece fevri, hesapsı, ölçüsüz idi. Menderes’’in soğukkanlıliğl, Mareşalde zerresiyle yoktu. Köprülü ne kadar patavatsı da olsa, Bölükbaşı’yla mukayese edilemezdi. Kurucular, CHP ekolünden gelmişlerdi. Ötekiler bütün hayatlarınca CHP'ye karşı olmuşlardı ve bütün hayatlarınca bir otoriteye tabi bulunmayı reddetmişlerdi. Zaten bir muhalefet partisine de kapağı ondan dolayı atmışlardı.

Orada da kendilerini bir disiplinin beklediğini gördüklerinde sudan çıkmış balı̆̆a döndüler (Toker, 2020: 173).

Cihad Baban da DP'de devam edegelen anlaşmazlıkların, sinsi sinsi çatışmaların, nüfuz mücadelesinin milletvekilleri maaş artışı meselesi üzerinden patlak verdiğini belirtmektedir. Baban, Genel İdare Kurulu'nda görev yapan ve muhalif grupta yer alan genç siyasetçilerin, Menderes'in, Köprülü'nün de desteğiyle kendileri üzerinde lüzumsuz bir hâkimiyet kurma sevdasından şikâyetçi olduklarını aktarmaktadır. Buna karşılık Menderes ve arkadaşlarının da, politikaya yeni girmiş bu gençlerin erken açıldıkları, görev yapmak için değil, şahsiyet kazanmak için başkaldırdıkları ve tahriklere kapıldıklarından yakındıklarını belirtmektedir (Baban, 2009: 27-28).

\section{SONUÇ}

İkinci Dünya Savaşı sonrası yeni oluşan şartlar çerçevesinde, iç ve dış faktörlerin zorlamasıyla da olsa nihayetinde Türkiye çok partili sisteme geçmiştir. İktidar partisi CHP ile muhalefetin merkezi konumundaki DP arasında iyi başlayan ilişkiler, 1947 yılının ortalarına gelindiğinde çok partili sisteme zarar verecek bir düzeye ulaşmıştır. Çok partili sistemi sürdürme kararlılığında olan Cumhurbaşkanı İsmet İnönü bu gidişata müdahale etme ihtiyacı duymuştur. Aslında CHP Genel Başkanı olmasına rağmen İnönü, partiler üstü bir tavır sergilemeye çalışmış ve bu bağlamda her iki partinin yetkilileriyle bir görüşme trafiği sürdürmüştür. İki parti arasındaki gerginliği azaltmak, aralarında bir güven oluşturmak ve dolayısıyla siyasi sistemi istikrara kavuşturmak amacıyla sürdürülen görüşmeler yaklaşık kırk gün sonra neticelenmiştir. İnönü, 11 Temmuz 1947 tarihinde radyoda yayımlanan ve tarihe '12 Temmuz Beyannamesi' olarak geçen Cumhurbaşkanlığı bildirisini yayımlamıştır.

İnönü, bildiride öncelikle iktidar ve muhalefet taraflarıyla yaptığı görüşmeleri aktarmıştır. Ardından her iki tarafın şikâyetlerine ve iddialarına yer vermiştir. Sonra da kendi tespitlerini ve ileriye dönük düşüncelerini dile getirmiştir. İnönü’nün muhalefet partisi DP'nin iddialarının kısmen haklılığını kabul etmesi ve meşru bir muhalefet partisi olduğunu ilan etmesi, çok partili sistemin devamı ve dolayısıyla demokratik düzenin Türkiye'de yerleşmesi açısında faydalı olmuştur. Ayrıca İnönü'nün her iki parti içerisindeki radikallerin temizlenmesini işaret etmesi yeni bir süreci başlatmıştır. Kısa bir süre sonra, CHP cephesinde sertlik yanlısı olan Başbakan Recep Peker istifa etmiştir.

12 Temmuz Beyannamesi iktidar-muhalefet gerginliğini belli bir süre azaltmış bu durum DP içerisindeki var olan anlaşmazlığın tam olarak ortaya çıkmasına neden olmuştur. DP içinde CHP iktidarına karşı sert bir politikanın izlenmesini savunan ve DP kurucularına karşı 'muhalif' konumunda olan grup, İnönü’nün partiler üstü bir pozisyon almasını ve taraflar arasında görüşmeler yapmasına karşı çıkmışlardır. Ortaya çıkan bildiriyi de kabul etmek istememişlerdir.

12 Temmuz Beyannamesi, bir anlamda DP yöneticilerini iki seçenek arasında tercih yapmak zorunda bırakmıştır. Ya CHP'ye karşı sert muhalefet dili terk edilerek iki taraf arasında bir güven iklimi oluşturulacak ya da kötü sonuçlar doğurabileceği tahmin edilen mevcut gerginlik durumu sürdürülecektir. DP yönetiminin çoğunluğu birinci seçeneği tercih etmişse de muhalifler de faaliyetlerini hızlandırmışlardır. Beyanname'nin yayımlanmasından kısa bir süre sonra yurt gezisine çıkan İnönü, yanına 
DP'den de bir milletvekilini almış ve bu milletvekili aracılığıyla hem DP içindeki sertlik yanlısı muhaliflerin tasfiyesini ima etmiş hem de DP içindeki istifa-tasfiye sürecini başlatacak olan milletvekilleri maaşlarının artırılması fikrini ortaya atmıştır.

1947 yılının sonlarında gündeme gelen milletvekilleri maaşlarının artııılması konusunda, DP kurucuları ile muhalifler arasında izlenecek politika konusunda anlaşmazlıklar ortaya çıkmıştır. Parti içerisinde, bir süre şahıslar üzerinden devam eden anlaşmazlık daha sonra kurucuların çoğunlukta olduğu Genel İdare Kurulu ile muhaliflerin çoğunlukta olduğu partinin Meclis Grup Yönetim Kurulu arasında sürmüştür. Bunun üzerine partide istifalar ve tasfiyeler başlamıştır. Böylece 1948 yılının ilk yarısında muhalif grup DP'den bir şekilde ayrılmış ve yeni bir parti kurmuştur. Bir yandan DP muhaliflerden arınarak daha homojen bir parti haline gelmiş, diğer taraftan ayrılanların kurduğu parti aracılığıyla Türkiye'de yeni bir siyasi hareket başlamıştır.

1950 genel seçimlerine giderken, henüz emekleme döneminde olan Türkiye'nin demokrasi süreci, 12 Temmuz Beyannamesi sayesinde ciddi bir badireyi atlatmış ve yaklaşık üç yıl sonra iktidara gelecek olan DP, 'kurucular'ın hâkimiyetinde iç sıkıntılarını atlatarak siyasi yürüyüşünü sürdürme imkânı bulmuştur. Ayrıca 12 Temmuz Beyannamesi, demokratik sistemin, hem partilerin içyapısı için hem de ülke yönetiminde, diyalog kültürüyle beraber sürdürülmesi gereken bir sistem olduğunu bir kez daha göstermiştir. İktidar ve muhalefet arasında diyalog sürecini başlatan, sürdüren ve neticelendiren Cumhurbaşkanı İnönü, ne yazık ki, yaklaşık on yıl sonra, Türkiye adım adım 27 Mayıs'a doğru yol alırken DP iktidarına karşı iktidar-muhalefet gerginliğini artıran baş aktörlerden biri olmuştur. Bazı şartların zorlamasıyla geçilen ve yeterli altyapısı olmayan Türkiye demokrasisi, 12 Temmuz Beyannamesi’yle bir eşiği geçmişse de, tüm kurum ve kurallarıyla geliştirilemediğinden sonraki dönemlerde sık sık kesintiye uğramıştır.

\section{KAYNAKÇA}

\section{TBMM Tutanakları}

TBMM Tutanak Dergisi, Dönem VII, Toplantı 3, C. 20, 1 Kasım 1945.

TBMM Tutanak Dergisi, Dönem VIII, Toplantı 1, C. 3, 18 Aralık 1946.

\section{Gazeteler}

Cumhuriyet, 10 Haziran 1946.

Cumhuriyet, 17 Haziran 1946.

Cumhuriyet, 25-26 Temmuz 1946.

Cumhuriyet, 6 Ağustos 1946.

Cumhuriyet, 12 Temmuz 1947.

Cumhuriyet, 17 Eylül 1947.

Cumhuriyet, 23 Aralık 1947.

Cumhuriyet, 17 Ocak 1948.

Cumhuriyet, 15 Şubat 1948.

Telif-Tetkik Eserler

Afşar, E. (2019). Türk Politik Tarihinde Demokrat Parti ve 1946 Programı, Van YYÜ İ̈BF Dergisi, 4(8), s. $273-295$.

Ağaoğlu, S. (2013). Siyasi Günlük Demokrat Parti’nin Kuruluşu, İstanbul: İletişim Yayınları.

Ahmad, F. (2010). Demokrasi Sürecinde Türkiye (1945-1980), (çev. Ahmet Fethi), İstanbul: Hil Yayın.

Akın, F. (2005). 12 Temmuz Beyannamesi’nin Türk Siyasi Tarihindeki Yeri ve Önemi, Sosyal Bilimler Dergisi, C. 7, S. 2, s. 92-109.

Akıncı, A. \& Usta, S. (2015). Türkiye'de Çok Partili Hayata Geçişte Etkili Olan İç Faktörlerin Analizi, KMÜ Sosyal ve Ekonomik Araştırmalar Dergisi, 17 (29), s. 41-52.

Ateş, A. E. \& Gökçeler, O. (2019). 12 Temmuz Beyannamesinin Gölgesinde Cumhurbaşkanı İsmet İnönü’nün Yurt Gezileri, Insan ve Insan, Y. 6, S. 21, s. 477-492.

Baban, C. (2009). Politika Galerisi Bir Devrin Hükümranları, İstanbul: Timaş Yayınları.

Bayar, C. (1986). Başvekilim Adnan Menderes, İstanbul: Tercüman Aile ve Kültür Kitaplığı Yayınları.

Çaylak, A. (2007). 1946-50 Döneminde Müfrit Muhafazakâr Demokratlar ve Türk Demokrasisinin Almış Olduğu Biçim, Ankara Üniversitesi SBF Dergisi, C. 62, S. 1.

Çaylak, A. \& Nişancı, Ş. (2012). Türkiye'de Çok Partili Siyasal Sürece Giriş: Demokrasiye Geçiş mi Siyasal Rejimin Restorasyonu mu?, Türkiye 'nin Politik Tarihi, (Ed. Adem Çaylak vd), Ankara: Savaş Yayınevi. 
Çiçek, A. C. (2018). Türkiye'de Çok Partili Siyasal Hayatın 'Garanti Belgesi’: 12 Temmuz Beyannamesi’nin Söylem Analizi, Curr Res Soc Sci, 4(2), s. 83-96.

Demirel, T. (2016). Türkiye’nin Uzun On Yllı Demokrat Parti İktidarl ve 27 Mayls Darbesi, İstanbul: İstanbul Bilgi Üniversitesi Yayınları.

Eraslan, C. (1998). Türkiye’de Çok Partili Siyasi Hayatın Kurulmasında Bir Dönüm Noktası: 12 Temmuz (1947) Beyannamesi, Ankara Üniversitesi Türk İnkllap Tarihi Enstitüsü Atatürk Yolu Dergisi, S. 22.

Erler Bayır, Ö. (2011). Türkiye'de Çok Partili Hayata Geçiş Sürecinde Solda Partileşme, İ. Ü. Siyasal Bilgiler Fakültesi Dergisi, No: 45, s. 45-72.

Eroğul, C. (2013). Çok Partili Düzenin Kuruluşu: 1945-1971, Geçiş Sürecinde Türkiye, (Drl. İrvin Cemil Schink ve E. Ahmet Tonak), İstanbul: Belge Yayınları.

Eroğul, C. (2013). Demokrat Parti Tarihi ve İdeolojisi, İstanbul: Yordam Kitap.

Goloğlu, M. (1982). Demokrasiye Geçiş 1946 - 1950, İstanbul: Kaynak Yayınları.

Güzelipek, Y. A. (2017). Demokrat Parti Döneminde Parti İçi Muhalefet ve Kırılma Anları: Tarihsel Bir Analiz, HISTORY STUDIES, Volume 9, Issue 3, s. 77-92.

Haytoğlu, E. (1994). Millet Partisi, Cumhuriyetçi Millet Partisi, Cumhuriyetçi Köylü Millet Partisi (1948 - 1960) (Yayımlanmamış Doktora Tezi), Dokuz Eylül Üniversitesi, Atatürk İlkeleri ve İnkılap Tarihi Enstitüsü.

İnönü, İ. (2017). Defterler 1919 - 1973, (Haz. Ahmet Demirel), İstanbul: Yap1 Kredi Yayınları.

Kabasakal, M. (1991). Türkiye’de Siyasal Parti Örgütlenmesi (1908 - 1960), İstanbul: Tekin Yayınevi.

Karpat, K. H. (2013). Türk Demokrasi Tarihi, Sosyal, Kültürel, Ekonomik Temeller, İstanbul: Timaş Yayınları.

Limoncuoğlu, A. (2018). Türkiye'de Üçüncü Yolun Başı; Millet Partisi (1948), Akademik Hassasiyetler, C. 5, S. 10, s. $145-155$.

Nadi, N. (1947). İnönü'nün Demeci, Cumhuriyet, 13 Temmuz 1947.

Sadak, N. (1945). Cumhur Başkanı'nın Güzel Nutku, Akşam, 20 Mayıs 1945.

Şeyhanlığlu, H. (2012). 12 Temmuz Beyannamesi'nin Siyasal Etkileri ve Önemi (Siyasal Hayatımızda Çatışma Çözümüne Bir Başarı Örneği), Süleyman Demirel Üniversitesi Sosyal Bilimler Enstitüsü Dergisi, S.16, s. 77-100.

Toker, M. (2020). Demokrasimizin İsmet Paşalı Yılları 1944-1973, Ankara: Bilgi Yayınevi.

Uran, H. (2017). Meşrutiyet, Tek Parti, Çok Parti Hatıralarım (1908-1950), İstanbul: Türkiye İş Bankası Kültür Yayınları.

Yaşar Teksoy, B. (2010). Demokrat Parti'de Parti İçi Demokrasi (1946 - 1960) (Yayımlanmamış Yüksek Lisans Tezi), Dokuz Eylül Üniversitesi, Sosyal Bilimler Enstitüsü. 